\title{
THE SURVIVAL OF STRAINS OF ENTERIC BACILLI IN THE BLOOD STREAM AS RELATED TO THEIR SENSITIVITY TO THE BACTERICIDAL EFFECT OF SERUM
}

\author{
By ROBERT J. ROANTREE* AND NICHOLAS C. PAPPAS \\ (From the Department of Medical Microbiology, Stanford University School of Medicine, \\ Stanford, Calif.)
}

(Submitted for publication July 13, 1959; accepted August 12, 1959)

Previous work has indicated that enteric bacillary strains vary greatly in their susceptibilities to the bactericidal effect of active human serum in vitro (1-3). Although minor differences in the bactericidal rates of sera from different individuals undoubtedly occur, these differences seem of small import when contrasted to the great variability in the sensitivities of the different strains to such sera (3). If the bactericidal activity of serum as measured in vitro reflects a corresponding activity in vivo, bacterial strains resistant to it should be much more capable of causing a sustained bacteremia after introduction into the circulation than are sensitive strains.

One survey has indicated that bacteria isolated from the blood of bacteremic patients are much more likely to be relatively resistant to the bactericidal action of serum than are those isolated from the stool or urine (3). Yet strains sensitive to the patient's own serum (3) or defibrinated blood (4) have been isolated from bacteremic patients.

One method of assessing the importance of the complement-dependent bactericidal system of serum relative to other native defense mechanisms might employ the simultaneous intravenous injection of a serum-sensitive and a serum-resistant strain into a laboratory animal. The survival rates of the two strains could then be determined by taking serial blood cultures. This paper will report such experiments.

The rabbit was chosen as a convenient experimental animal although our tests in vitro have shown its serum to be somewhat less bactericidal than that of the sheep or the guinea pig. Results to be reported below indicate that rabbit serum is comparable to, although less active than, human serum in its bactericidal activity.

The experiments to be described utilized pairs

* Recipient of the Lederle Medical Faculty Award. of strains of gram-negative bacilli. One strain of each pair was sensitive to serum and the other resistant. They could be distinguished from each other by their differing antibiotic sensitivities. Five combinations of eight strains were used, and every pair was tested for sensitivity to human and to rabbit sera in vitro. Comparable numbers of each strain of a pair were suspended together in saline solution and injected intravenously into rabbits. The number of viable organisms of each strain remaining in the blood stream at various times after injection was then determined by quantitative blood cultures.

\section{MATERIALS AND METHODS}

Tests of human and rabbit sera in vitro. Preliminary experiments to determine the comparability of the bactericidal action of human and of rabbit sera in vitro were conducted. The method used was that of subjecting 10fold dilutions of a 20 hour broth culture of a test organism to the action of $1 \mathrm{ml}$. of undiluted active serum for a two hour period. The number of organisms killed during this time was determined by loop subcultures to agar (3). The numbers killed by human serum were determined by taking the majority result of a test which included at least three human sera. Ordinarily the action of one rabbit serum was compared to that of the three human sera, but at times, as many as three rabbit sera were included in the test.

Experiments with combinations of bacterial strains. Six strains of Escherichia coli, one strain of Klebsiella, and one strain of Aerobacter were used in these experiments. These strains had been isolated from human urine at Stanford University Hospital. Each had been subcultured once in broth for 20 hours; this culture was divided into a number of portions to be used as starter culture, and these were stored at $-20^{\circ} \mathrm{C}$.

These particular strains were selected from a group known to be sensitive to streptomycin and resistant to tetracycline or vice versa. Strains which had opposite sensitivities to the antibiotics and to killing by serum were then used in the experiments as pairs.

Young adult male rabbits weighing from 2.7 to $3.5 \mathrm{Kg}$. were used in all experiments.

Rabbit blood was drawn aseptically by cardiac punc- 
TABLE I

Bactericidal action of normal human and rabbit sera in vitro against the bacterial strains used for the injection of the rabbits

\begin{tabular}{|c|c|c|c|c|c|c|c|}
\hline \multirow{2}{*}{$\frac{\text { Combination }}{\text { II }}$} & \multirow{2}{*}{$\begin{array}{c}\text { Serum used } \\
\text { Rabbit }\end{array}$} & \multirow{2}{*}{$\begin{array}{c}\text { Bacterial strains } \\
\text { E. coli } \underset{129 \mathrm{R}}{119 \mathrm{R}}\end{array}$} & \multicolumn{5}{|c|}{ Percentage of inoculum surviving } \\
\hline & & & $\begin{array}{c}10 \min . \\
100 \\
0\end{array}$ & $\begin{array}{c}20 \text { min. } \\
102 \\
0\end{array}$ & $\begin{array}{c}30 \text { min. } \\
100 \\
0\end{array}$ & $\begin{array}{c}40 \mathrm{~min} . \\
103 \\
0\end{array}$ & $\begin{array}{c}60 \mathrm{~min} . \\
100 \\
0\end{array}$ \\
\hline & Human & $\begin{array}{r}\text { E. coli } 119 \mathrm{R} \\
129 \mathrm{~S}\end{array}$ & $\begin{array}{r}84 \\
0\end{array}$ & $\begin{array}{r}67 \\
0\end{array}$ & $\begin{array}{r}61 \\
0\end{array}$ & $\begin{array}{r}50 \\
0\end{array}$ & $\begin{array}{r}33 \\
0\end{array}$ \\
\hline \multirow[t]{2}{*}{ III } & Rabbit & E. coli $\begin{array}{c}118 \mathrm{R} \\
192 \mathrm{~S}\end{array}$ & $\begin{array}{r}73 \\
1\end{array}$ & $\begin{array}{r}56 \\
0\end{array}$ & $\begin{array}{r}64 \\
1\end{array}$ & $\begin{array}{r}67 \\
1\end{array}$ & $\begin{array}{r}131 \\
0\end{array}$ \\
\hline & Human & E. coli $118 \mathrm{R}$ & $\begin{array}{r}64 \\
0\end{array}$ & $\begin{array}{r}34 \\
0\end{array}$ & $\begin{array}{r}21 \\
0\end{array}$ & $\begin{array}{r}24 \\
0\end{array}$ & $\begin{array}{r}30 \\
0\end{array}$ \\
\hline \multirow[t]{2}{*}{ IV } & Rabbit & E. coli $\begin{array}{r}108 \mathrm{R} \\
130 \mathrm{~S}\end{array}$ & $\begin{array}{r}100 \\
32\end{array}$ & $\begin{array}{r}100 \\
17\end{array}$ & $\begin{array}{r}106 \\
10\end{array}$ & $\begin{array}{r}129 \\
5\end{array}$ & $\begin{array}{r}165 \\
3\end{array}$ \\
\hline & Human & $\begin{array}{r}\text { E. coli } 108 \mathrm{R} \\
130 \mathrm{~S}\end{array}$ & $\begin{array}{r}100 \\
1\end{array}$ & $\begin{array}{r}101 \\
0\end{array}$ & $\begin{array}{r}93 \\
0\end{array}$ & $\begin{array}{r}108 \\
0\end{array}$ & $\begin{array}{r}113 \\
0\end{array}$ \\
\hline \multirow[t]{2}{*}{ V } & Rabbit & $\begin{array}{l}\text { Aerobacter 125R } \\
\text { Klebsiella 27S }\end{array}$ & $\begin{array}{r}96 \\
5\end{array}$ & $\begin{array}{r}83 \\
0\end{array}$ & $\begin{array}{r}95 \\
0\end{array}$ & $\begin{array}{r}90 \\
0\end{array}$ & $\begin{array}{r}111 \\
0\end{array}$ \\
\hline & Human & $\begin{array}{l}\text { Aerobacter 125R } \\
\text { Klebsiella 27S }\end{array}$ & $\begin{array}{r}92 \\
2\end{array}$ & $\begin{array}{r}99 \\
0\end{array}$ & $\begin{array}{r}93 \\
0\end{array}$ & $\begin{array}{r}92 \\
0\end{array}$ & $\begin{array}{r}111 \\
0\end{array}$ \\
\hline
\end{tabular}

ture, allowed to clot for one hour, and then centrifuged for 20 minutes at $2,000 \mathrm{rpm}$. The serum was harvested and apportioned in appropriate amounts into sterile serological tubes. These were placed at $-20^{\circ}$ C. within two hours of drawing the blood.

Human blood was drawn from the antecubital vein of healthy donors and processed in a manner similar to that used for the rabbit blood.

Streptomycin ${ }^{1}$ and tetracycline ${ }^{2}$ from commercial sources were used to make up the antibiotic plates.

Tests of serum and bacterial combinations in vitro. Each pair of bacterial strains was selected so that one member was serum-sensitive and the other serum-resistant. One was streptomycin-sensitive, tetracycline-resistant, and the other had the opposite antibiotic sensitivities. Each strain was cultured separately by adding a $0.1 \mathrm{ml}$. portion of the thawed starter culture to a tube containing $4.5 \mathrm{ml}$. of peptic digest of liver broth and incubating this at $37^{\circ} \mathrm{C}$. for 20 hours. The cultures were diluted separately in saline to previously determined suitable dilutions and then combined in volumes which would yield approximately equal numbers of each strain. To a $0.4 \mathrm{ml}$. aliquot of this combination, $3.6 \mathrm{ml}$. of active serum was added. This addition resulted in inocula of from 1,000 to 3,000 organisms of each strain per ml. of serum. The mixture was rapidly pipetted up and down 10 times and placed in the $37^{\circ}$ water bath. Precisely the same procedure was followed with heated serum in a

${ }^{1}$ Streptomycin sulfate, E. R. Squibb \& Sons, New York, N. Y.

2 Achromycin Hydrochloride ${ }^{\$}$, Lederle Laboratories, New York, N. Y. control tube. At the intervals noted in Figure 1 and Table $\mathrm{I}, 0.1 \mathrm{ml}$. aliquots were inoculated into duplicate pour plates containing nutrient agar alone and into plates with agar containing $10 \mu \mathrm{g}$. per $\mathrm{ml}$. of tetracycline or streptomycin. Plate counts were done after incubation for 24 hours at $37^{\circ} \mathrm{C}$. Since good agreement was found between duplicate plates, the counts were averaged and

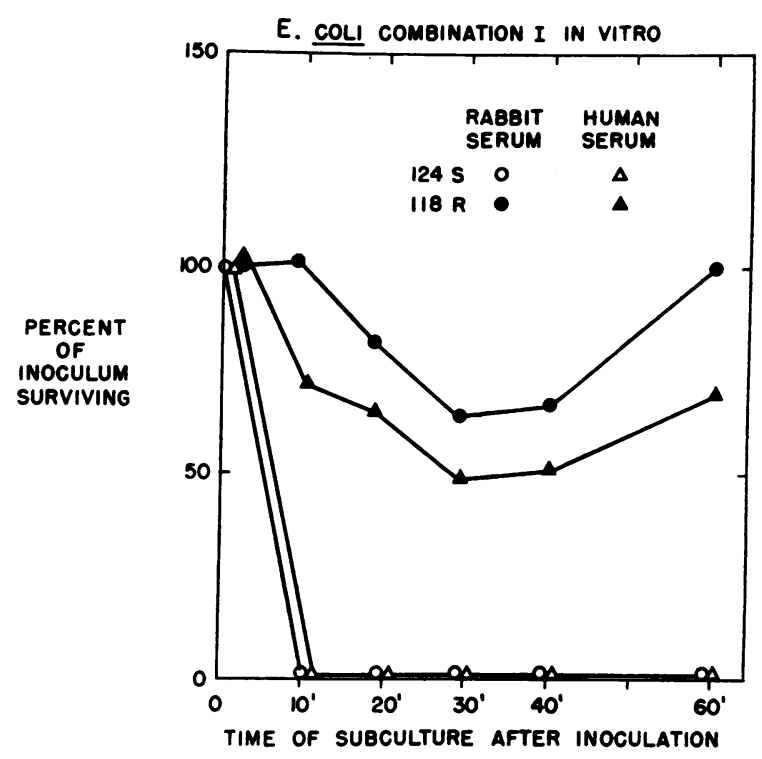

Fig. 1. Bactericidal Action of Normal Human and Rabbit Sera IN Vitro Against the Two Strains of E. COLI Making up Combination I 
expressed as the percentage of original inoculum surviving.

For each individual strain, plate counts were performed on plain agar and each of the antibiotic agars to insure that the properties of the strains remained constant. There was no evidence of resistant colonies developing from an antibiotic-sensitive strain, nor of suppression of the streptomycin-resistant strain by streptomycin. However, tetracycline regularly suppressed 10 to 20 per cent of the colonies of strains resistant to it.

Tests of bacterial combinations in vivo. As in the experiments in vitro, 20 hour broth cultures were used. These were centrifuged, the supernatant broths removed and the bacteria resuspended uniformly in normal saline solution. A $0.5 \mathrm{ml}$. aliquot of each suspension was removed for dilution to $10^{-6}$ for viable bacterial counts. The two strains were then mixed in that proportion which previous experience indicated would yield approximately equal numbers of each for injection into the rabbit.

Injection was made via the marginal ear vein. Blood samples of $0.6 \mathrm{ml}$. were withdrawn from the veins of the opposite ear at 1, 15 and 30 minutes, and at two hours following injection, using a $1.5 \mathrm{ml}$. syringe which had been rinsed in heparin. The samples were immediately diluted in sodium citrate-saline solution, the first $1: 10$, and all others 1:2. Aliquots of $0.1 \mathrm{ml}$. were removed and plated on nutrient, streptomycin and tetracycline agars. At 24, 48, and sometimes at 96 hours, $8 \mathrm{ml}$. blood samples were taken by cardiac puncture, diluted $1: 2$ in sodium citrate, and $1 \mathrm{ml}$. aliquots plated on nutrient and antibiotic agar.

Representative colonies from each plate showing growth were subcultured in broth and then streaked on each type of antibiotic agar to insure that neither strain had changed in its sensitivity to antibiotics and that the potencies of the antibiotic plates were correct. Several isolates from each type of agar on which growth appeared, following inoculation with blood drawn 24 and 48 hours after infection of a rabbit, were tested for their sensitivities to rabbit and to human serum to insure that the antibiotic plates were distinguishing the strains and to determine whether any change in sensitivity to serum had occurred.

\section{RESULTS}

\section{Comparative effects of human and rabbit sera upon gram-negative bacilli in vitro}

Table II presents the results from experiments in vitro comparing the action of human and of rabbit sera. In all, 46 tests were done on 30 different bacillary strains using sera from 16 different rabbits. Those strains tested more than once were

TABLE II

Comparison of bactericidal effect of normal human and rabbit sera

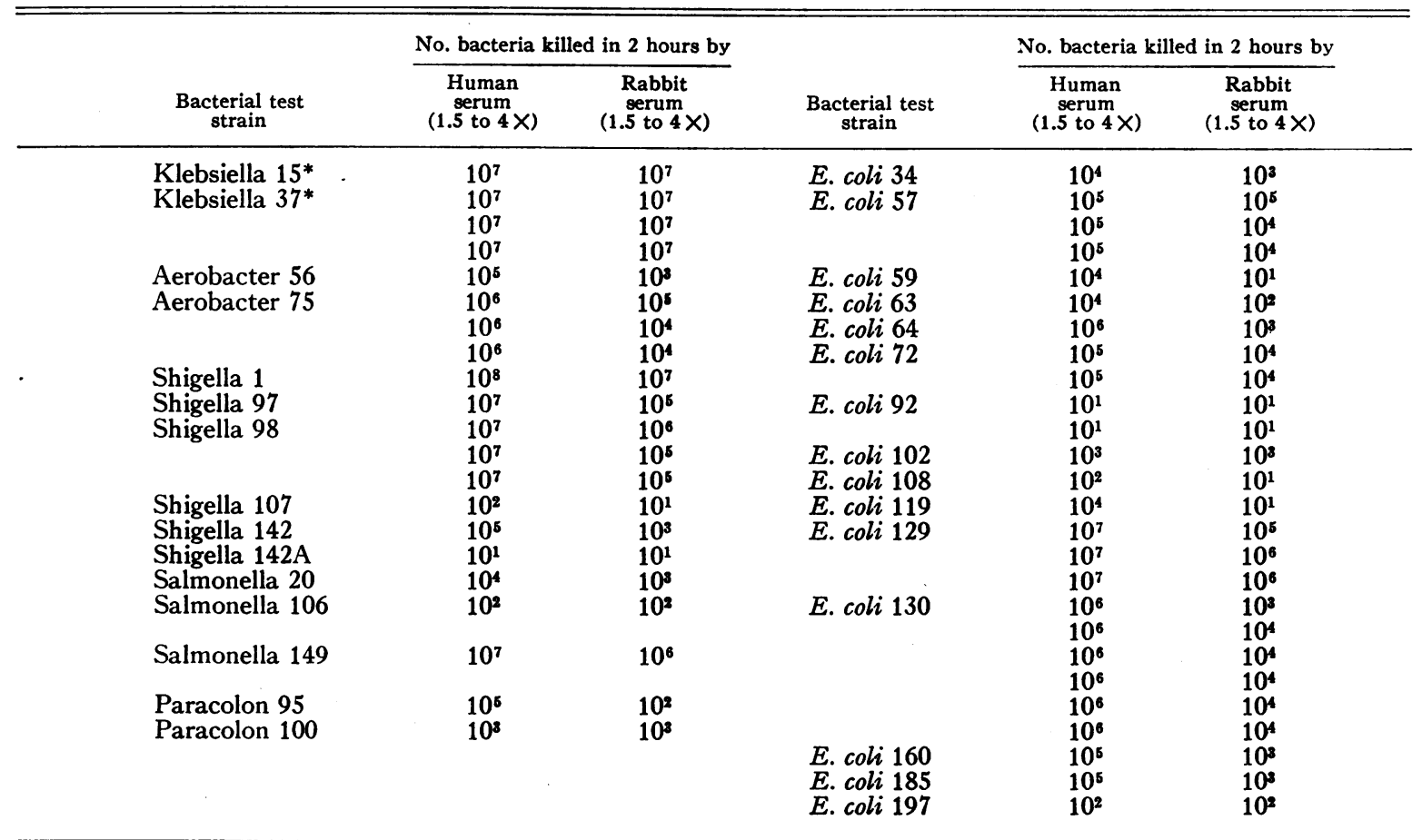

* In these tests neither human nor rabbit serum was tested with a greater inoculum so that differences between them would not be evident. 
tested against sera from different rabbits. It may be noted that those six strains which were relatively resistant to human serum, being killed at a rate of less than $1 \times 10^{4}$ (designated $10^{3}$ or less in the table) bacteria per $\mathrm{ml}$. in the two hours, were also resistant to rabbit serum. The other strains of moderate or great sensitivity to human serum were usually sensitive, but less so, to rabbit serum. In no case was a strain more sensitive to rabbit serum. As with human sera, little difference was noted in the action of sera from different rabbits. It may be stated in general that rabbit serum is bactericidal for the same bacterial strains as is human serum, though to a lesser degree.

It having been determined that the rabbit was a suitable animal for such experiments, four combinations of six strains of $E$. coli and one combination of strains of Klebsiella and Aerobacter were exposed in vitro to the action of undiluted sera from two different human donors and from two different rabbits. Figure 1 and Table I present the results of one such experiment with each of the five combinations (the letter " $S$ " designates the sensitive and " $R$ " the resistant strain). Results of duplicate experiments were very similar. Figure 1 shows the great difference in sensitivities of the two strains used in Combination I. Inspection of Table I reveals a similar pattern of results of experiments with the other four combinations. Where differences occur between the actions of rabbit and human sera, the latter are more active. Heated rabbit or human serum had no bactericidal activity against any strain.

\section{Survival of serum-sensitive and serum-resistant gram-negative bacilli in vivo}

Figure 2 and Table III present data from duplicate experiments performed with each of the five combinations and compare the survival rates in the blood stream of the sensitive and resistant strains of each combination after intravenous injection.

Combination I was composed of strains $124 \mathrm{~S}$ and 118R. In Figure 2 it may be noted that the number of bacteria of each strain cultured from

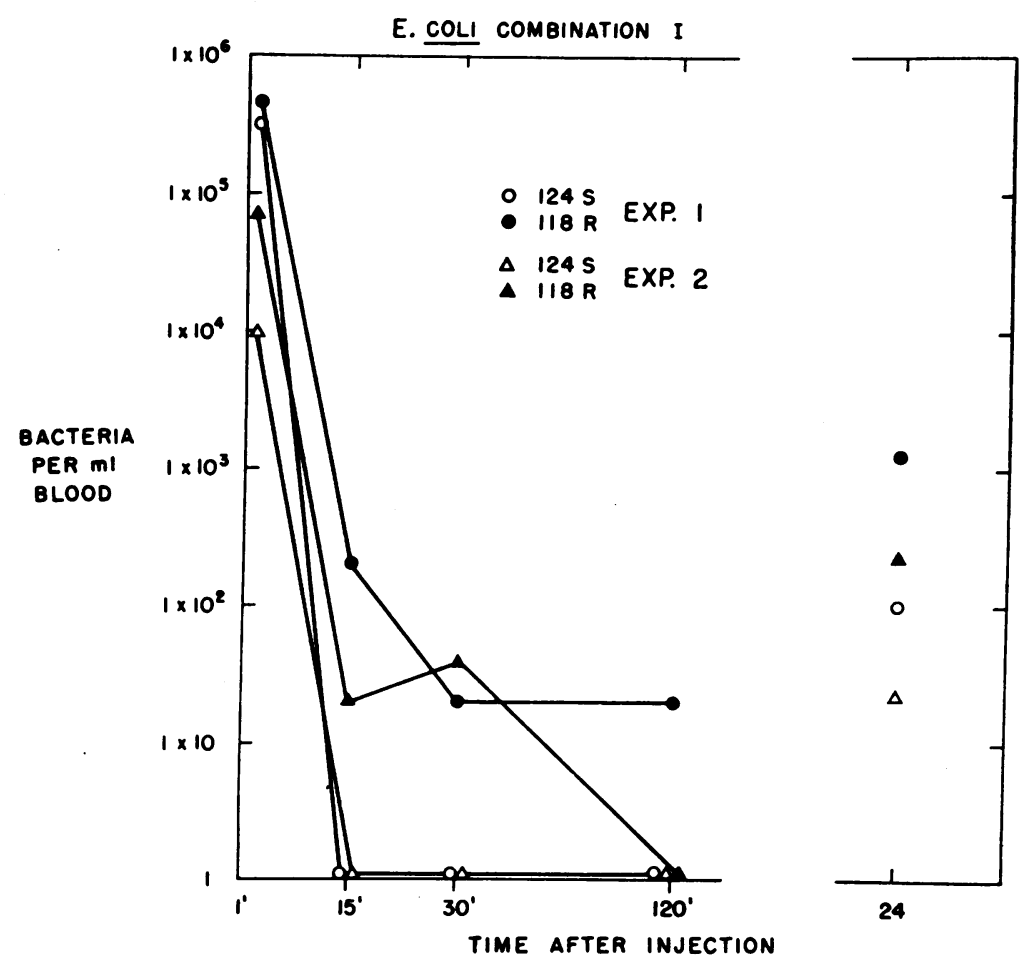

Fig. 2. Number of Organisms of Each Strain of Combination I Surviving in the Blood Stream of the Rabbit Following Intravenous INJECTION 
TABLE III

Rate of disappearance of bacterial strains in the blood stream of the rabbit following intravenous injection

\begin{tabular}{|c|c|c|c|c|c|c|c|c|c|c|}
\hline $\begin{array}{c}\text { Bacterial } \\
\text { combination }\end{array}$ & Expt. & Bacterial strain & $\begin{array}{c}\text { No. } \\
\text { bacteria } \\
\text { injected } \\
\times 10^{8}\end{array}$ & & No. bac & $\begin{array}{l}\text { a per m } \\
\text { ter I.V. }\end{array}$ & $\begin{array}{l}\text { lood at } \\
\text { lection }\end{array}$ & rvals & & \\
\hline \multirow[t]{2}{*}{ II } & 1 & $\begin{array}{r}\text { E. coli } 119 \mathrm{R} \\
129 \mathrm{~S}\end{array}$ & $\begin{array}{l}5.2 \\
3.6\end{array}$ & $\begin{array}{c}\underset{1}{\min .} \\
79,000 \\
16,000\end{array}$ & $\begin{array}{r}15 \\
\text { min. } \\
100 \\
0\end{array}$ & $\begin{array}{r}30 \\
\text { min. } \\
0 \\
0\end{array}$ & $\begin{array}{r}120 \\
\min . \\
20 \\
20\end{array}$ & $\begin{array}{r}24 \\
h r . \\
0 \\
0\end{array}$ & $\begin{array}{r}48 \\
h r . \\
0 \\
0\end{array}$ & $\begin{array}{c}96 \\
h r \\
0 \\
0\end{array}$ \\
\hline & 2 & $\begin{array}{r}\text { E. coli } 119 \mathrm{R} \\
129 \mathrm{~S}\end{array}$ & $\begin{array}{l}4.4 \\
5.1\end{array}$ & $\begin{array}{r}140,000 \\
55,000\end{array}$ & $\begin{array}{r}40 \\
100\end{array}$ & $\begin{array}{l}0 \\
0\end{array}$ & $\begin{array}{r}60 \\
0\end{array}$ & $\begin{array}{r}14 \\
0\end{array}$ & $\begin{array}{l}0 \\
0\end{array}$ & $\begin{array}{l}\mathbf{0} \\
\mathbf{0}\end{array}$ \\
\hline \multirow[t]{2}{*}{ III } & 1 & E. coli $\underset{129 \mathrm{~S}}{118 \mathrm{R}}$ & $\begin{array}{l}2.8 \\
1.8\end{array}$ & $\begin{array}{r}670,000 \\
85,000\end{array}$ & $\begin{array}{r}200 \\
20\end{array}$ & $\begin{array}{r}20 \\
0\end{array}$ & $\begin{array}{r}40 \\
0\end{array}$ & $\begin{array}{r}576 \\
8\end{array}$ & $\begin{array}{r}42 \\
0\end{array}$ & $\begin{array}{l}0 \\
0\end{array}$ \\
\hline & 2 & $\begin{array}{r}\text { E. coli } 118 \mathrm{R} \\
129 \mathrm{~S}\end{array}$ & $\begin{array}{l}6.0 \\
5.6\end{array}$ & $\begin{array}{l}600,000 \\
240,000\end{array}$ & $\begin{array}{r}20 \\
0\end{array}$ & $\begin{array}{r}20 \\
0\end{array}$ & $\begin{array}{l}0 \\
0\end{array}$ & $\begin{array}{r}60 \\
6\end{array}$ & $\begin{array}{r}12 \\
2\end{array}$ & $\begin{array}{l}0 \\
0\end{array}$ \\
\hline \multirow[t]{2}{*}{ IV } & 1 & E. coli $\begin{array}{r}108 \mathrm{R} \\
130 \mathrm{~S}\end{array}$ & $\begin{array}{l}3.9 \\
4.0\end{array}$ & $\begin{array}{r}1,900,000 \\
430,000\end{array}$ & $\begin{array}{r}48,000 \\
620\end{array}$ & $\begin{array}{r}240 \\
40\end{array}$ & $\begin{array}{r}100 \\
0\end{array}$ & $\begin{array}{r}264 \\
34\end{array}$ & & \\
\hline & 2 & E. coli $\begin{array}{r}108 \mathrm{R} \\
130 \mathrm{~S}\end{array}$ & $\begin{array}{l}3.8 \\
3.0\end{array}$ & $\begin{array}{r}1,400,000 \\
21,000\end{array}$ & $\begin{array}{r}32,000 \\
40\end{array}$ & $\begin{array}{r}440 \\
20\end{array}$ & $\begin{array}{r}270 \\
40\end{array}$ & $\begin{array}{l}0 \\
0\end{array}$ & $\begin{array}{l}0 \\
0\end{array}$ & \\
\hline \multirow[t]{2}{*}{ V } & 1 & $\begin{array}{l}\text { Aerobacter 125R } \\
\text { Klebsiella 27S }\end{array}$ & $\begin{array}{l}4.5 \\
4.4\end{array}$ & $\begin{array}{r}480,000 \\
1,200,000\end{array}$ & $\begin{array}{r}580 \\
20\end{array}$ & $\begin{array}{r}160 \\
0\end{array}$ & $\begin{array}{r}20 \\
0\end{array}$ & $\begin{array}{l}0 \\
0\end{array}$ & $\begin{array}{l}0 \\
0\end{array}$ & \\
\hline & 2 & $\begin{array}{l}\text { Aerobacter } 125 \mathrm{R} \\
\text { Klebsiella } 27 \mathrm{~S}\end{array}$ & $\begin{array}{l}2.6 \\
4.9\end{array}$ & $\begin{array}{l}310,000 \\
110,000\end{array}$ & $\begin{array}{r}300 \\
0\end{array}$ & $\begin{array}{r}20 \\
0\end{array}$ & $\begin{array}{r}20 \\
0\end{array}$ & $\begin{array}{l}0 \\
0\end{array}$ & $\begin{array}{l}0 \\
0\end{array}$ & \\
\hline
\end{tabular}

the blood was rapidly reduced d iring the first two hours. The resistant strain appeared to be cleared at a slower rate, and in Experiment 1 there were 20 resistant organisms per ml. culturable at two hours.

In both experiments there was a continuing or recurring bacteremia at 24 hours. In Experiment 1 , there were 1,240 colonies of $118 \mathrm{R}$ per $\mathrm{ml}$. of blood compared with 104 colonies of $124 \mathrm{~S}$. In Experiment 2, 232 organisms of $118 \mathrm{R}$ per $\mathrm{ml}$. were detected compared with 28 of $124 \mathrm{~S}$.

Table III reveals similar pictures with the other four combinations tested. There was a rapid clearing of both strains in the first two hours, and with each $E$. coli combination, there was at least one experiment in which bacteremia was present at 24 hours. Only the Klebsiella-Aerobacter Combination $\mathrm{V}$ was undetectable at 24 hours in both experiments.

If the data from all 10 experiments are considered, the serum-resistant strains were cleared at a slightly slower rate than the sensitive ones in nine experiments and at a similar rate in the other. In six of the experiments, bacteremia was present at 24 hours. In one of these six only the resistant strain was present. In the other five, both strains were present, but the resistant organisms outnumbered the sensitive ones usually about 10 to 1 .

Bacteremia persisted for 48 hours after Combination III was injected. In Experiment 1, only the resistant strain was present, whereas in Experiment 2 , both strains were present, but organisms of the resistant strain were the more numerous.

In each of the four combinations of $E$. coli described above, the strain resistant to serum was also the strain resistant to tetracycline. As noted in vitro, the tetracycline agar suppressed a certain number of colonies of each strain supposedly resistant to it. Streptomycin did not have this effect. Thus the counts from the experiments in vivo of resistant organisms are probably low. If the plain agar plate count minus the streptomycin plate count were taken rather than the tetracycline plate count, the number of resistant organisms at 24 hours reported for the $E$. coli experiments would be as much as doubled, but this alteration makes little difference to the general conclusions.

With each combination of E. coli, 5 to 15 colo- 
nies which had appeared on the plain agar plate inoculated 24 hours after injection were picked and tested for their sensitivities to serum in vitro. Of the 63 tested, 61 were resistant to serum and two were sensitive. This ratio of 30 to 1 is not incompatible with that of 10 or 20 to 1 noted by the antibiotic marker technique.

Forty-three colonies obtained from the 24 hour blood cultures in tetracycline agar were tested for streptomycin sensitivity and serum resistance. All showed the same qualities as had the parent strain.

Twenty-eight colonies isolated from the blood 24 or 48 hours after the injection of Combinations I or III and representing the sensitive strains $124 \mathrm{~S}$ and 129S showed the same sensitivity to human serum as before injection. In Combination III, cultures from four colonies of strain 129S from the 24 hour streptomycin plate showed the same degree of sensitivity when tested against two rabbit sera as the strain had shown before passage. Cultures from the two colonies on the streptomycin plate prepared 48 hours after injection showed the same degree of sensitivity to the infected rabbit's own serum taken at 48 hours as well as to serum from another rabbit. These data support the conclusions that only colonies of the sensitive strain were isolated on the streptomycin agar and that a change in sensitivity of the bacterial strain did not take place during passage.

\section{DISCUSSION}

Preliminary experiments showed that rabbit serum was bactericidal in vitro for the same strains as was human serum although its action was somewhat less pronounced. This same relationship between human and rabbit sera has been noted in experiments in which pooled sera were compared with respect to their action against $S$. typhi (5). As with the human sera, there were only minor differences among the rates at which sera from different rabbits killed any particular test strain. These results indicated that the rabbit would be a suitable animal in which to investigate the relative importance of the bactericidal activity of serum as a barrier to the invasion and persistence of bacteria in the blood stream.

The bacterial strains of each combination selected for the injection of the rabbits were vastly different in their degree of sensitivity to serum in vitro. Although in 9 out of the 10 experiments in the rabbit, the resistant strain disappeared from the blood stream at a less rapid rate than the sensitive one, the numbers of both strains were quickly diminished, and the differences in the rate of clearance between the two were unimpressive. If the resistant strains are considered absolutely resistant to serum as $E$. coli strain $108 \mathrm{R}$ appears to be, then it must be concluded that factors other than the bactericidal activity of serum play the major role in clearing the blood stream of bacteria. These results are in agreement with those of another study in which the injected strain of $E$. coli was known to be resistant to serum (6). That study, as well as a number of others $(7-10)$, has shown quite clearly that the injected bacteria are removed as they pass through the liver and spleen, presumably by the reticuloendothelial system. A lesser number is removed during passage through the pulmonary circulation.

Despite the evidence above that the role played by the bactericidal property of serum is a minor one, the finding that in each of the six experiments in which bacteria were found at 24 hours following inoculation, the resistant strain outnumbered the sensitive strain ordinarily about 10 to 1 , may adequately explain our observations that strains resistant to serum are more apt to appear in bacteremias. Bacterial counts of blood from patients bacteremic with $E$. coli or $S$. typhi rarely exceed 10 organisms per ml. and are usually less (11). Under such circumstances, it would seem that the chances of spread of a bacterium via the blood stream would be greatly enhanced if it were resistant to the bactericidal effect of serum.

The finding of viable bacteria of strains very sensitive to serum in blood cultures 24 and 48 hours after inoculation of the experimental animal indicates that the bactericidal action of serum in vivo is much less effective than testing in vitro would indicate. In these experiments it was shown that the strains isolated 24 and 48 hours following injection still retained the same sensitivity to human and to rabbit sera that had characterized them previously. Two of the isolates from a blood culture made 48 hours after infection were shown to be sensitive to the infected rabbit's own serum. These sensitive strains may have been protected by an intracellular locus or perhaps they were be- 
ing fed continuously into the blood stream from cells of the reticuloendothelial system, and serum factors had not had time to affect them. The evidence for believing that the complement-dependent bactericidal system is relatively inactive in vivo has been reviewed by Maaløe (12).

\section{SUMMARY}

Rabbit serum was found to be bactericidal for strains of bacteria sensitive to human serum.

Pairs of enteric bacillary strains were injected intravenously into rabbits. One member of the pair was sensitive to the bactericidal action of serum, the other resistant. Five combinations of eight different strains were used and each combination was tested twice.

Both resistant and sensitive strains were rapidly cleared from the blood stream during the first two hours, the resistant strains being removed at a slightly slower rate in 9 of the 10 experiments.

Bacteremia was detected 24 hours following injection in six instances, and 48 hours after injection in two. Ordinarily, organisms of the resistant strain outnumbered those of the sensitive strain about 10 to 1 . The bacteria of the sensitive strain which were isolated 24 or 48 hours after injection showed no change in their degree of sensitivity to the bactericidal action of serum.

It is concluded from these experiments that the bactericidal properties of serum play, at most, a minor role in freeing the blood stream of bacteria, but that, nevertheless, this role may be of some importance. This conclusion is reinforced by our previous observations that most spontaneously occurring bacteremias caused by gram-negative bacilli are caused by serum-resistant organisms.

\section{REFERENCES}

1. Mackie, T. J., and Finkelstein, M. H. Natural bactericidal antibodies: Observations on the bactericidal mechanism of normal serum. J. Hyg. (Lond.) 1931, 31, 35.

2. Wardlaw, A. C., and Pillemer, L. The properdin system and immunity. V. The bactericidal activity of the properdin system. J. exp. Med. 1956, 103, 553.

3. Roantree, R. J., and Rantz, L. A. A study of the relationship of the normal bactericidal activity of human serum to bacterial infection. J. clin. Invest. 1960, 39, 72.

4. Khairat, O. The bactericidal power of the blood for the infecting organism in bacteraemia. J. Path. Bact. 1946, 58, 359.

5. Muschel, L. H., Chamberlin, R. H., and Osawa, E. Bactericidal activity of normal serum against bacterial cultures. I. Activity against Salmonella typhi strains. Proc. Soc. exp. Biol. (N. Y.) 1958, 97, 376.

6. Rogers, D. E., and Melly, M. A. Studies on bacteriemia. III. The blood stream clearance of Escherichia coli in rabbits. J. exp. Med. 1957, 105, 113.

7. Bull, C. G. The fate of typhoid bacilli when injected intravenously into normal rabbits. J. exp. Med. 1915, 22, 475.

8. Manwaring, M. H., and Fritschen, W. Study of microbic tissue affinity by perfusion methods. J. Immunol. 1923, 8, 83.

9. Ørskov, J., Jensen, K. A., and Kobayashi, K. Studien über Breslauinfektion der Mäuse, speziell mit Rücksicht auf die Bedeutung des Retikuloendothelialgewebes. Z. Immun.-Forch. 1928, 55, 34.

10. Sullivan, F. L., Neckermann, E. F., and Cannon, P. R. The localization and fate of bacteria in the tissues. J. Immunol. 1934, 26, 49.

11. Reynes, V. Densité de l'infection sanguine dans les bactériémies et septicémies. C. R. Soc. Biol. (Paris) 1947, 141, 261.

12. Maaløe, O. Some aspects of the normal, antibacterial defence. Acta path. microbiol. scand. 1948, 25, 237. 